\title{
A Penicillium expansum Glucose Oxidase-Encoding Gene, GOX2, Is Essential for Gluconic Acid Production and Acidification During Colonization of Deciduous Fruit
}

\author{
Shiri Barad, ${ }^{1,3}$ Sigal Brown Horowitz, ${ }^{1}$ Oren Moscovitz, ${ }^{1}$ Amnon Lichter, ${ }^{1}$ Amir Sherman, ${ }^{2}$ and \\ Dov Prusky ${ }^{1}$
}

${ }^{1}$ Department of Postharvest Science of Fresh Produce; ${ }^{2}$ Department of Genomics, ARO, the Volcani Center, Bet Dagan, 50250, Israel; ${ }^{3}$ Department of Plant Pathology and Microbiology, Faculty of Agricultural, Food and Environmental Quality Sciences, the Hebrew University of Jerusalem, Rehovot 76100, Israel

Submitted 2 January 2012. Accepted 13 February 2012.

\begin{abstract}
Penicillium expansum, the causal agent of blue mold rot, causes severe postharvest maceration of fruit through secretion of total D-gluconic acid (GLA). Two $P$. expansum glucose oxidase (GOX)-encoding genes, GOX1 and GOX2, were analyzed. GOX activity and GLA accumulation were strongly related to $G O X 2$ expression, which increased with pH to a maximum at $\mathrm{pH}$ 7.0, whereas $G O X 1$ was expressed at pH 4.0, where no GOX activity or extracellular GLA were detected. This differential expression was also observed at the leading edge of the decaying tissue, where GOX2 expression was dominant. The roles of the $G O X$ genes in pathogenicity were further studied through i) development of $P$. expansum goxRNAi mutants exhibiting differential downregulation of $G O X 2$, ii) heterologous expression of the $P$. expansum GOX2 gene in the nondeciduous fruit-pathogen $P$. chrysogenum, and iii) modulation of GLA production by $\mathrm{FeSO}_{4}$ chelation. Interestingly, in $P$. expansum, pH and GLA production elicited opposite effects on germination and biomass accumulation: $26 \%$ of spores germinated at $\mathrm{pH}$ 7.0 when GOX activity and GLA were highest whereas, in $P$. chrysogenum at the same $\mathrm{pH}$, when GLA did not accumulate, $72 \%$ of spores germinated. Moreover, heterologous expression of $P$. expansum GOX2 in $P$. chrysogenum resulted in enhanced GLA production and reduced germination, suggesting negative regulation of spore germination and GLA production. These results demonstrate that pH modulation, mediated by GLA accumulation, is an important factor in generating the initial signal or signals for fungal development leading to host-tissue colonization by $P$. expansum.
\end{abstract}

Penicillium expansum is a destructive phytopathogen, capable of causing decay in deciduous fruit during postharvest handling and storage. The pathogen is not considered to be host

\section{S. Barad and S. B. Horowitz contributed equally to this study.}

Nucleotide and amino acid sequences for the GOX1 and GOX2 genes of Penicillium expansum are available in the GenBank database under accession numbers AY669127 (GOX1) and GQ324948 (GOX2).

Corresponding author: D. Prusky; Telephone: +972-3-9683610/3880; Fax: +972-3-9683622; E-mail: dovprusk@ volcani.agri.gov.il

* The $\boldsymbol{e}$-Xtra logo stands for "electronic extra" and indicates that two supplementary figures and one supplementary table are published online. Also, Figures 3 and 5 appear in color online. specific among deciduous fruit and typically causes extensive maceration of the infected tissue, presumably by a common mechanism (Prusky et al. 2004). Direct tissue acidification, is achieved by secretion of organic acids, of which gluconic acid is the principal one produced by $P$. expansum (Hadas et al. 2007; Prusky and Yakoby 2003; Prusky et al. 2004).

Early studies demonstrated that the $\mathrm{pH}$ regulatory system ensures that secreted enzymes and metabolites, as well as specific membrane proteins, are produced at the optimal $\mathrm{pH}$ that enables them to fully perform their physiological functions (Eisendle et al. 2003; Prusky and Yakoby 2003). In Penicillium spp., pathogenicity has been attributed, among other things, to secretion of polygalacturonases (PGs), which depolymerize pectin, thereby causing tissue maceration (Sánchez-Torres and González-Candelas 2003; Yao et al. 1996). Interestingly, expression of PEPG1, which encodes $\mathrm{PG}$, is upregulated under acidic conditions (Prusky et al. 2004).

In $P$. expansum, gluconic acid production is catalyzed by oxidation of $\beta$-D-glucose to D-glucono- $\delta$ lactone and $\mathrm{H}_{2} \mathrm{O}_{2}$ by glucose oxidase (GOX) (E.C. 1.1.3.4), which uses molecular oxygen as an electron acceptor (Bruchmana et al. 1987; Kobayashi et al. 1998). Previously, two putative genes (GOX1 and GOX2) were identified in $P$. expansum and found to exhibit significant homology with other fungal GOX proteins (Hadas et al. 2007). Moreover, transcript analysis of the GOX family in infected tissue showed that GOX2 expression was higher than that of $G O X 1$, suggesting that $G O X 2$ might be important for $P$. expansum pathogenicity (Hadas et al. 2007). The relationship between gluconic acid and $P$. expansum pathogenicity was further confirmed by the finding that isolates that induced larger-diameter lesions compared with nonaggressive strains produced significantly more gluconic acid. In addition, GOX2 expression and lesion size were both reduced when the oxygen level was reduced during fruit storage (Hadas et al. 2007).

Although the involvement of organic acid has been studied in detail for Sclerotinia and Botrytis host-pathogen interactions (Kunz et al. 2006; Magro et al. 1984; Manteau et al. 2003; Moksia et al. 1996; Ruijter et al. 1999), data on regulation of organic acid production by $P$. expansum during pathogenicity are scarce (Hadas et al. 2007; Magnuson and Lasure 2004; Prusky et al. 2004). The present study provides supporting evidence for the role of gluconic acid secretion during colonization by $P$. expansum. Taken together, a set of differing approaches that involved alteration of $G O X$ expression, generation of downregulated GOX P. expansum strains, and expression of $P$. expansum GOX2 in the nondeciduous fruit pathogen $P$. chrysogenum 
(Barkai-Golan 1974) suggest that GOX2 is probably the major gene responsible for gluconic acid production and tissue acidification during pathogenicity of P. expansum.

\section{RESULTS}

\section{Predicted structure and domain organization of the GOX1 and GOX2 proteins.}

In a previous study (Hadas et al. 2007), two GOX-encoding sequences, GOX1 and GOX2, were identified in $P$. expansum (Pe-21) (Table 1). Analysis of the complete sequence of GOX2 and of a partial sequence of GOX1 from $P$. expansum revealed that these are members of the glucose-methanol-choline oxidoreductase family of flavoenzymes, in which the general topology is conserved. Protein alignment of $P$. expansum GOX2 (GQ324948) showed $67 \%$ identity to $P$. expansum GOX1 (AY669127), a high degree (70\%) of identity to GOX from Aspergillus niger (GOX1 ACR56326), and 68\% identity to GOX (CAE47418) from $P$. variabile, whereas GOX1 showed a high degree $(84 \%)$ of identity to $P$. chrysogenum GOX (XP 002560814 ) and $69 \%$ identity to $P$. variabile GOX (CAE47418). Identity among further GOX proteins of acidifying species is presented in the phylogenetic tree in Supplementary Figure S1B. In silico analysis of cellular localization of the deduced amino acid sequences of GOX2 by means of the prediction algorithms SignalP-HMM model (Nielsen et al. 1999), PSORTII (Nakai and Horton 1999), and TargetP (Emanuelsson et al. 2000) indicated a probability of 0.999 of the presence of signal peptides in GOX2, with a cleavage site between positions 16 and 17 (ATA-LP) (Nielsen et al. 1999), which supports the likelihood that it's a secreted protein.

\section{P. expansum GOX expression, GOX activity,} and D-gluconic acid (GLA) production are pH-dependent.

To determine whether GOX expression and total GLA production are regulated by $\mathrm{pH}$, the $\mathrm{Pe}-21$ strain was grown in buffered secondary medium (SM) adjusted to $\mathrm{pH}$ levels 4.0, 5.0, 7.0, or 9.0. Quantitative reverse-transcription polymerase chain reaction (RT-PCR) data demonstrated that GOX1 and $G O X 2$ were differentially expressed. GOX2 expression was highest at $\mathrm{pH} 7.0$ and decreased by 68, 83, and $89 \%$ at $\mathrm{pH} 9.0$, 5.0, and 4.0, respectively. In contrast, GOX1 expression was highest at $\mathrm{pH} 3.0$ and decreased by 58, 59, and $90 \%$ at $\mathrm{pH} 5.0$, 7.0, and 9.0, respectively (Fig. 1A). The combined amounts of total GLA found within mycelia and in the culture filtrate (Fig. 1B) followed the pattern of GOX2 expression: low (1.9 mg per gram of dry weight $[\mathrm{DW}]^{-1}$ ) at $\mathrm{pH} 4.0$, and 3 and 2.4 times greater at $\mathrm{pH} 7.0$ and 9.0, respectively (Fig. 1B). At all pH levels, the amount of intracellular GLA remained within the range of 1.2 to $1.4 \mathrm{mg}$ per gram of $\mathrm{DW}$. When the initial $\mathrm{pH}$ of the SM was 7.0, the final $\mathrm{pH}$ fell dramatically $(\Delta \mathrm{pH}=1.90)$ whereas, in contrast, when the initial $\mathrm{pH}$ was 4.0 , the final $\mathrm{pH}$ hardly changed. These results reveal differential regulation of $G O X 2$ and GOX1 at acidic and neutral-alkaline $\mathrm{pH}$ levels, suggesting that GOX2 made the main contribution to the observed acidification process.

To improve understanding of the $\mathrm{pH}$ regulation of GLA production, GOX activity at different time points during growth in buffered and nonbuffered SM was compared at $\mathrm{pH}$ levels ranging from 4.0 to 6.86. In nonbuffered $\mathrm{SM}$ at an initial $\mathrm{pH}$ of 6.5, the highest GOX activity was detected $15 \mathrm{~h}$ after subculturing, and the maximal $\mathrm{pH}$ decrease (to 4.6) was observed $5 \mathrm{~h}$ later (Fig. 2A). However, in buffered SM with an initial $\mathrm{pH}$ of 6.5 , maximal activity $(2.28 \mathrm{U} / \mathrm{ml})$ was reached $55 \mathrm{~h}$ after subculturing, and there were minor $\mathrm{pH}$ changes throughout (Fig. 2B). When GOX activity was monitored in the buffered $\mathrm{SM}$ at $\mathrm{pH}$ levels of 4.0 to 6.86 , it was observed that, as the $\mathrm{pH}$ rose, GOX activity and GLA accumulation increased almost 3,000- and 162-fold, respectively (Table 2), which suggests that the initial $\mathrm{pH}$ is an important controlling factor for GOX expression, GOX activity, and GLA accumulation.

In support of the data obtained in vitro, an in vivo analysis of GOX1 and GOX2 expression at the leading edge of the Penicillium decay in pear fruit showed that GOX2 expression was more than $70 \%$ higher than that of GOX1 (Supplementary Fig. $\mathrm{S} 2$ ). These data further confirm that GOX1 and GOX2 are differentially regulated during pathogenicity, and that GOX2 is probably the main factor contributing to GLA accumulation.

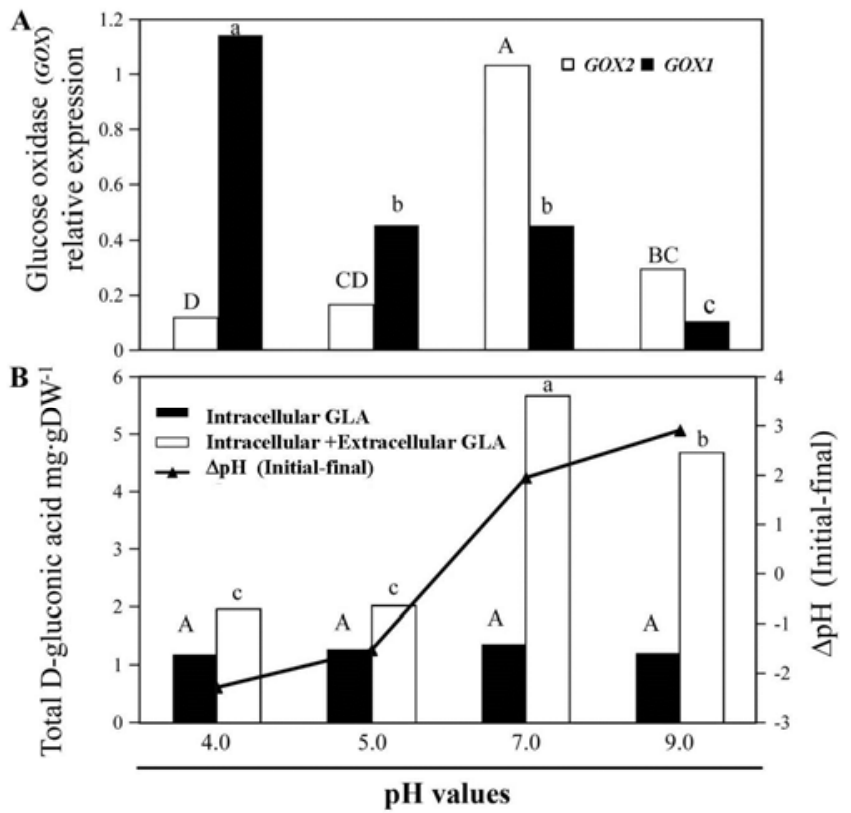

Fig. 1. Effect of $\mathrm{pH}$ on the expression profiles of glucose oxidase $(G O X) 1$ and GOX2 and of intracellular and extracellular total D-gluconic acid (GLA) accumulation by Penicillium expansum. A, Relative expression

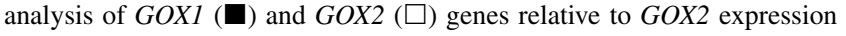
values at $\mathrm{pH}$ 4.0. B, Intracellular (ם) and total (intracellular + extracellular) ( $\square$ ) DGA level and $\Delta \mathrm{pH}(\boldsymbol{\Delta})$. Cultures were sampled $48 \mathrm{~h}$ after mycelia of $P$. expansum were transferred to buffered secondary medium adjusted to four $\mathrm{pH}$ levels $(4.0,5.0,7.0$, and 9.0). Three replicates are shown for each $\mathrm{pH}$ value. Mycelial biomass was sampled for transcription analysis of GOX1 and GOX2 and intracellular GLA content; culture filtrate was used for extracellular GLA determination and $\mathrm{pH}$ measurement. Columns and symbols with different letters are significantly different at $P \leq 0.05$ according to the Tukey-Kramer multiple comparison test. Experiments were repeated three times and results of a single representative experiment are shown.

Table 1. Penicillium expansum strains used in this study

\begin{tabular}{lll}
\hline Strain $^{\text {a }}$ & \multicolumn{1}{c}{ Genotype } & \multicolumn{1}{c}{ Source } \\
\hline Pe-21 & Wild-type P. expansum & Hadas et al. 2007 \\
gox1:gox2RNAi strains: TPe130; TPe141; TPe114; TPe116 & RNAi gox1: gox2:hygR & This study \\
Pc-31 & Wild=type $P$. chrysogenum & This study, Israel \\
TPc $_{\text {gox } 2}$ & Pc $_{\text {gox2:PhleomycinR }}$ & This study \\
\hline
\end{tabular}

${ }^{\text {a }}$ Strains starting with $\mathrm{T}$ are original transformants. 
Molecular characterization of goxRNAi mutants.

The GOX gene family of $P$. expansum was downregulated by means of RNAi technology (Fig. 3A). In total, 75 hygromycinresistant transformants were recovered, and all were tested for acidification of the medium after $48 \mathrm{~h}$ of growth in SM, with Alizarin Red S used as a pH indicator (Fig. 3A). Seven transformants that were found to partially reduce the $\mathrm{pH}$ of the growth media were purified to single spores on hygromycin B selection medium, and several rounds of hyphal transfer from the edge of the colony were performed. Four of these strains were used for further characterization. To confirm goxRNA $i$ construct integration, the putative transformants were subjected to PCR screening with the internal and external primers FHyg and RHyg amplifying the internal hygromycin cassette (Fig. 3B; Supplementary Table S1). PCR analysis of transformants TPe130, TPe141, TPe114, and TPe116 (Table 1) generated the expected 750-kb PCR fragment (Fig. 3B).

Physiological analysis of the RNA $i$ mutants revealed similar growth and sporulation patterns when they were grown on potato dextrose agar (PDA). Functional characterization of $R N A i$

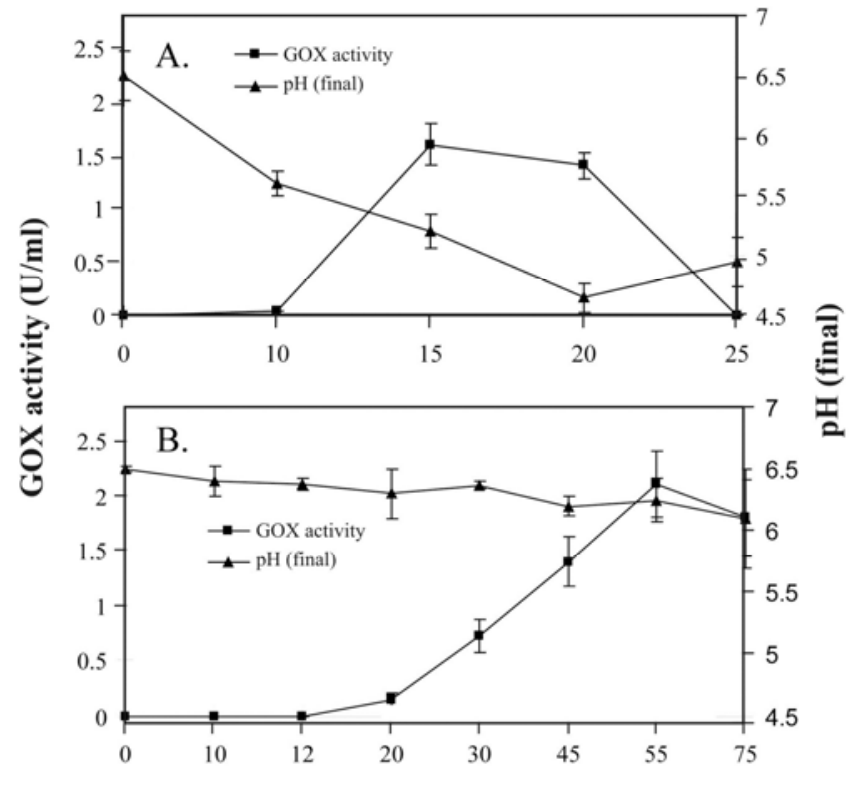

Time after transfer $(\mathrm{h})$

Fig. 2. Glucose oxidase (GOX) activity and $\mathrm{pH}$ changes induced by Penicillium expansum. GOX activity and final $\mathrm{pH}$ in culture filtrate were determined at different time points after $P$. expansum hyphae were transferred to secondary medium that was adjusted to $\mathbf{A}$, unbuffered $\mathrm{pH} 6.5$ or $\mathbf{B}$, buffered to $\mathrm{pH} 6.5$ with $0.2 \mathrm{M}$ potassium phthalate buffer. Average values \pm standard deviation of three replicates of GOX activity $(\mathrm{U} / \mathrm{ml})$ and $\mathrm{pH}$, as functions of time are presented. Experiments were repeated three times and results of a single representative experiment are shown. mutants showed significant downregulation of $G O X 1$ by a factor of approximately 3 and downregulation of GOX2 by a factor of up to 14 during growth in SM (Table 3). These findings indicate that the downregulation of $G O X 1$ that was observed in gox2-RNAi mutants might have resulted from high sequence homology between GOX1 and GOX2. However, the significant decreases in GLA production and disease development observed for gox2-RNAi are attributed mainly to the reduction in GOX2 expression (Table 3). Reduction of disease development on 'Golden Delicious' apple was greatest for strains Pe141 and

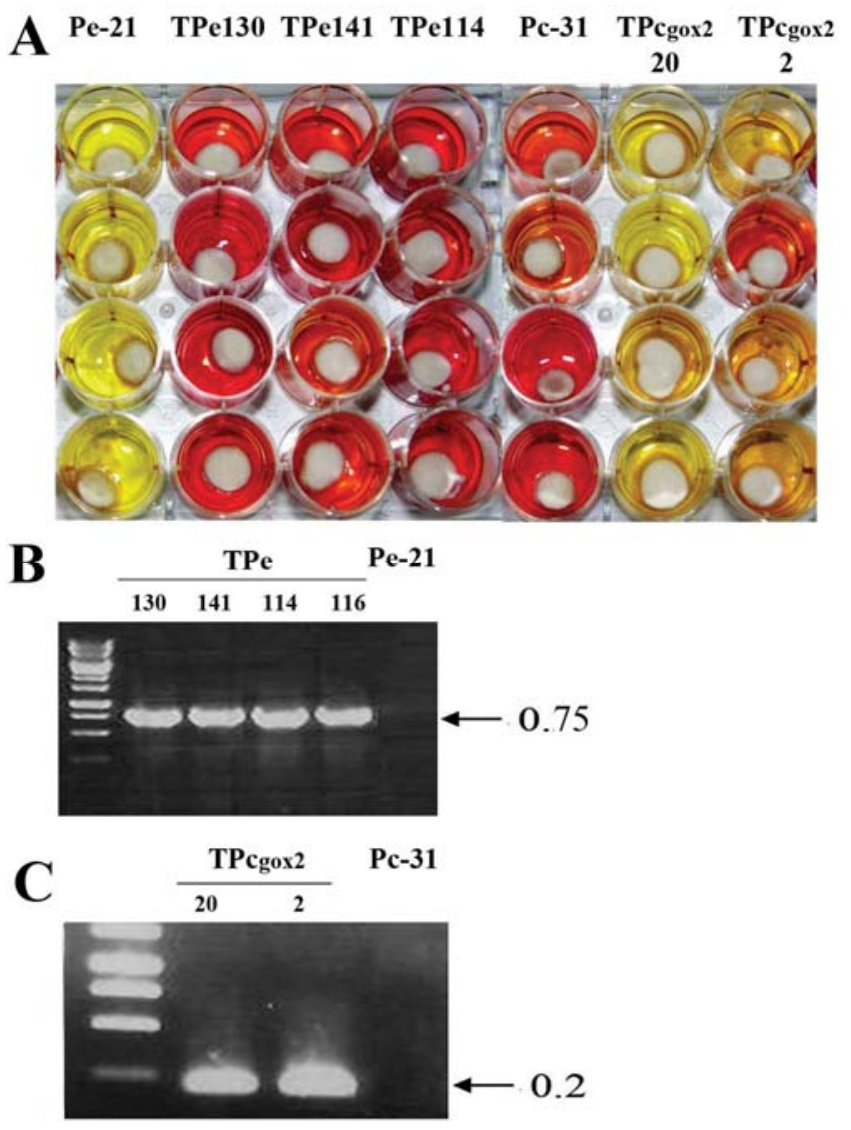

Fig. 3. Selection and analysis of Penicillium expansum gox-RNAi mutants and $P$. chrysogenum-glucose oxidase $(G O X) 2$-expressing strains. A, Rapid assay for screening putative $G O X$-disrupted strains for acidification capacity. The $\mathrm{pH}$ indicator Alizarin Red S was used to determine media acidification $24 \mathrm{~h}$ after transfer to secondary medium adjusted to $\mathrm{pH} 7.0$ in a 48well tray. Yellow staining indicates reduction of $\mathrm{pH}$ of the corresponding strain from 7.0 to less than 4.5. B, Downregulated GOX TPe mutants were confirmed by amplification of $0.75-\mathrm{kb}$ polymerase chain reaction (PCR) product of the hygromycin (hyg) resistance gene. C, GOX2 expression in strains $\mathrm{TPc}_{\mathrm{gox} 2}-2$ and $\mathrm{TPc}_{\mathrm{gox} 2}-20$ was confirmed by amplification of $0.2-\mathrm{kb}$ PCR product of the phleomycin $($ ble $)$ resistance gene.

Table 2. Effect of ambient $\mathrm{pH}$ on glucose oxidase (GOX) activity and total D-gluconic acid accumulation in the culture filtrate of Penicillium expansum ${ }^{\mathrm{a}}$

\begin{tabular}{|c|c|c|c|c|}
\hline \multicolumn{2}{|l|}{ pH } & \multicolumn{3}{|c|}{ GOX specific activity } \\
\hline Initial & Final & (U/mg protein) & GOX activity $\left(\mathrm{U}_{\text {gDW }} \mathbf{- 1}^{-1}\right)$ & Total D-gluconic acid $\left(\mathrm{mg} \mathrm{gDW}^{-1}\right)$ \\
\hline 4 & 3.92 & $0.25 \pm 0.25$ & $0.0169 \pm 0.011$ & $0.067 \pm 0.005$ \\
\hline 4.53 & 4.45 & $0.27 \pm 0.06$ & $0.037 \pm 0.01$ & $0.053 \pm 0.016$ \\
\hline 4.95 & 4.88 & $0.25 \pm 0.09$ & $0.027 \pm 0.01$ & $0.027 \pm 0.011$ \\
\hline 5.55 & 5.41 & $0.77 \pm 0.25$ & $0.114 \pm 0.03$ & $0.065 \pm 0.016$ \\
\hline 6.14 & 5.85 & $80 \pm 16$ & $15.510 \pm 2.42$ & $4.489 \pm 2.57$ \\
\hline 6.86 & 6.07 & $203 \pm 14$ & $47.570 \pm 3.78$ & $10.940 \pm 1.26$ \\
\hline
\end{tabular}

${ }^{\mathrm{a}}$ The analysis was carried out after transferring the mycelia grown in primary media to inducing secondary media adjusted to the desired $\mathrm{pH}$ with $0.2 \mathrm{M}$ potassium phthalate buffer. After $48 \mathrm{~h}$, the final pH, GOX activity, and gluconic acid were measured. GOX activity is expressed as GOX specific activity in $\mathrm{U} / \mathrm{mg}$ of protein and as GOX activity in U per gram of dry weight (gDW). Averages values \pm standard deviation of three replicates of GOX activity, accumulated total D-gluconic acid per gram DW of mycelium and $\mathrm{pH}$ measured are presented. 
Pe130 (68 and 48\%, respectively), whereas downregulation of GOX2 was almost 93\%. However, in strains Pe114 and Pe116, in which only $80 \%$ downregulation of GOX2 was measured, an intermediate level of GLA and partial attenuation of disease development were observed (Table 3). Similar levels of disease development inhibition were observed when the isolates were inoculated onto ‘Granny Smith' apple (Table 3).

\section{Expression of $P$. expansum GOX2}

\section{in the nondeciduous fruit pathogen $P$. chrysogenum.}

A BLAST search for P. expansum GOX1 and GOX2 homologs in the $P$. chrysogenum genome indicated high homology (87\% identity) to the $P$. expansum $G O X 1$ sequence but none to its GOX2 sequence. To extend the functional analysis of the role of $P$. expansum GOX2, the entire GOX2 coding region $(2.53 \mathrm{~kb})$ was cloned into the $\mathrm{pCH} 1$ vector, which was used to transform the $P$. chrysogenum Pc-31 strain. Integration of pCH1 into $P$. chrysogenum was confirmed by amplification of the $0.2-\mathrm{kb}$ band of the ble gene in strains $\mathrm{TPc}_{\mathrm{gox} 2}$ (Fig. $3 \mathrm{C}$ ). Strain $\mathrm{TPc}_{\mathrm{gox} 2}-20$, along with the Pc-31 strain, were used for further physiological studies.

As expected, strains Pe-21, Pc-31, and $\mathrm{TPc}_{\mathrm{gox} 2}-20$ exhibited similar expression levels of GOX1 (Fig. 4A). No GOX2 transcripts were detected in strain Pc-31 but transcripts were present in strains $\mathrm{Pe}-21$ and $\mathrm{TPc}_{\text {gox } 2}-20$ (Fig. 4A). Comparison with the amounts of total GLA secreted by strains Pe-21 and $\mathrm{TPc}_{\text {gox } 2}-20$ showed 96 and $95 \%$, respectively, higher GLA accumulation than the levels secreted by strain Pc-31. The $\mathrm{pH}$ of the medium decreased from the initial $\mathrm{pH} 7.0$ to $\mathrm{pH} 6.0$ for strain Pc-31, whereas it fell to 3.7 and 4.4, respectively, for strains $\mathrm{Pe}-21$ and $\mathrm{TPc}_{\mathrm{gox} 2}-20$ (Fig. 4B), which suggests that $G O X 2$ has a major role in the GLA production and acidification processes induced by Penicillium spp.

To analyze the contribution of GOX2 expression in $\mathrm{TPc}_{\mathrm{gox} 2^{-}}$ 20 , we next examined the ability of the $\mathrm{TPc}_{\text {gox } 2}$ mutant to colonize and produce conidia on pear fruit, which is usually more susceptible than apple fruit. Five days after inoculation of pear fruit, diameters of lesions caused by strains Pe-21 and $\mathrm{TPc}_{\mathrm{gox} 2^{-}}$ 20 were $22.2 \pm 1.5$ and $4.3 \pm 0.1 \mathrm{~mm}$, respectively, whereas no typical symptoms of disease development were observed with strain Pc-31. The effect of GOX2 expression was further demonstrated by analyzing Penicillium spp. surface-colonization capability, and it was found that strain Pc-31 consistently produced fewer conidia than strain Pe-21 or $\mathrm{TPc}_{\text {gox } 2}-20$ (Fig. 5A). Conidial production on pear disks by Pc-31 was less than $75 \%$ compared with strain Pe-21 or $\mathrm{TPc}_{\mathrm{gox} 2}-20$ (Fig. 5B). However, conidial counts were increased by the addition of 5 or $10 \mathrm{mM}$ GLA to Pc-31-inoculated pear disks (Fig. 5C). It should be noted that the addition of similar amounts of GLA to strain Pe21 or $\mathrm{TPc}_{\mathrm{gox} 2}-20$ did not lead to any increase in conidial counts
(Fig. 5C). These results demonstrate that pathogenic development was induced by functional GOX2, indicating that GLA is likely to play an important role in fungal colonization of pear tissue.

\section{Effect of iron on GLA accumulation} and surface colonization by $P$. expansum.

In light of the suggestion that hydroxy acids such as GLA are cation chelators (Guerinot 1994), we decided to determine the effects of divalent cations $\mathrm{ZnCl}_{2}, \mathrm{MgSO}_{4}, \mathrm{CaCl}_{2}, \mathrm{CuCl}_{2}$, and $\mathrm{FeSO}_{4}$, at a concentration of $1 \mathrm{mM}$, on GLA accumula-

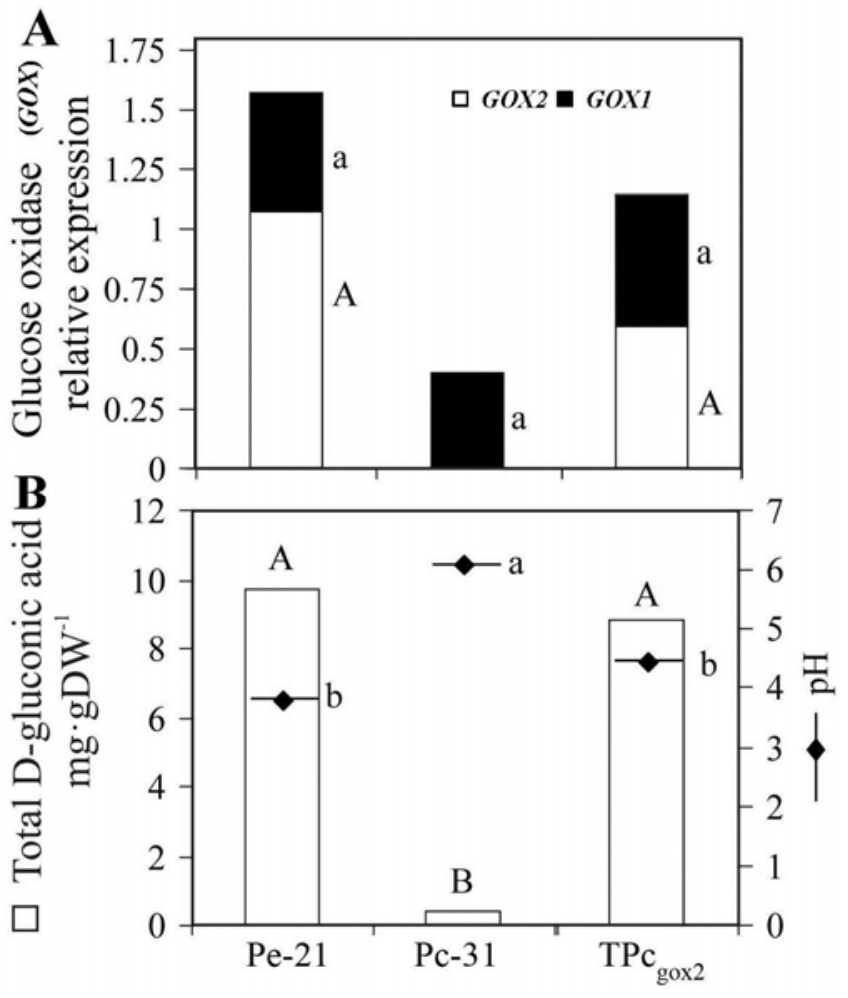

Fig. 4. Analysis of glucose oxidase $(G O X) 1$ and $G O X 2$ expression and of D-gluconic acid accumulation by Penicillium expansum (Pe-21), P. chrysogenum (Pc-31), and the recombinant $P$. chrysogenum $\mathrm{TPc}_{\mathrm{gox}_{2}-20}$ strains. A, Expression analysis of GOX1 ( $\square$ ) and GOX2 ( $\square$ ) by comparison with GOX2 expression in the Pe-21 strain. B, Analysis of gluconic acid ( $\square$ ) and acidification capability $(\bullet)$ of the $\mathrm{TPc}_{\text {gox } 2}-20$ by comparison with strains Pe-21 and Pc-31. Relative expression values of GOX1 and GOX2 are the averages of three replicates. Columns and symbols with different letters are significantly different at $P \leq 0.05$ according to the Tukey-Kramer multiple comparison test. Experiments were repeated three times and results of a single representative experiment are shown.

Table 3. Relation between glucose oxidase (GOX) expression in RNAi mutants of Penicillium expansum and their pathogenicity on 'Golden Delicious' (GD) and 'Granny Smith' (GS) apple ${ }^{\mathrm{a}}$

\begin{tabular}{|c|c|c|c|c|c|}
\hline \multirow[b]{2}{*}{ Strain } & \multicolumn{2}{|c|}{ Relative expression $^{b}$} & \multirow[b]{2}{*}{ Gluconic acid $\left(\mathrm{mg} \mathrm{gDW}^{-1}\right)^{\mathbf{d}}$} & \multicolumn{2}{|c|}{ Inhibition (\%) ${ }^{\mathrm{c}}$} \\
\hline & GOX1 & GOX2 & & GD & GS \\
\hline Pe-21 & $1.00 \pm 0.48$ & $1.00 \pm 0.42$ & $6.91 \pm 0.15$ & 0 & 0 \\
\hline TPe116 & $0.31 \pm 0.11$ & $0.17 \pm 0.05$ & $4.22 \pm 0.23$ & $7.0 *$ & $21.3 *$ \\
\hline TPe114 & $0.35 \pm 0.11$ & $0.19 \pm 0.01$ & $3.21 \pm 0.53$ & $18.5^{*}$ & $15.6^{*}$ \\
\hline TPe130 & $0.24 \pm 0.09$ & $0.08 \pm 0.01$ & $2.77 \pm 0.15$ & $47.9 *$ & $51.5 *$ \\
\hline TPe141 & $0.26 \pm 0.10$ & $0.07 \pm 0.01$ & $0.83 \pm 0.08$ & $69.0 *$ & $74.2^{*}$ \\
\hline
\end{tabular}

\footnotetext{
${ }^{\text {a }}$ Relative expressions of GOX1 and GOX2 in the RNAi mutants were compared with their expression in the wild-type strain.

${ }^{\mathrm{b}}$ Averages values \pm standard deviation of three replicates of $G O X$ relative expression and accumulated total D-gluconic acid are presented. Experiments were repeated three times and the results of a single representative experiment are shown.

${ }^{\mathrm{c}}$ Percent inhibition of colonization on apple fruit 4 days after inoculation. Comparison between inhibition of colonization spreading from three inoculations of Pe-21 and of the gox $2 R N A i$ mutants on the same apple. Inhibition percentages of the gox $2 R N A i$ with an asterisk (*) are significantly different from that of Pe-21 at $P \leq 0.05$ according to the Tukey-Kramer multiple comparison test.

${ }^{\mathrm{d}}$ Gluconic acid production; DW = dry weight.
} 
tion. At $1 \mathrm{mM}$, only $\mathrm{FeSO}_{4}$ reduced the level of total GLA secreted by strain Pe-21 after $48 \mathrm{~h}$ (results not shown). The addition of $1 \mathrm{mM} \mathrm{FeSO}_{4}$ reduced the measured level of total GLA by $90 \%$ and, thus, repressed acidification of the medium $(\mathrm{pH}=$ $6.7 \pm 0.16$ versus $3.7 \pm 0.24$ in the control) (Fig. $6 \mathrm{~A}$ ); the transcript expression of GOX2 under these conditions fell by $95 \%$ but the level of $G O X 1$ expression did not differ from that in the control (Fig. 6B).

To establish the association among Fe availability, GLA accumulation, and Pe-21 colonization, we examined the effects of increasing concentrations of $\mathrm{Fe}$, as $\mathrm{FeSO}_{4}$ at 0 to $2 \mathrm{mM}$, on surface colonization and fungal conidiation of pear fruit disks. Fe concentrations of $0.5 \mathrm{mM}$ or more had significant effects on surface colonization, as determined by counts of conidia (Fig. $6 \mathrm{C})$. The inhibitory effect of $\mathrm{Fe}$ at 1 and $2 \mathrm{mM}$ on conidiation was attenuated by addition of $10 \mathrm{mM}$ gluconic acid but not to
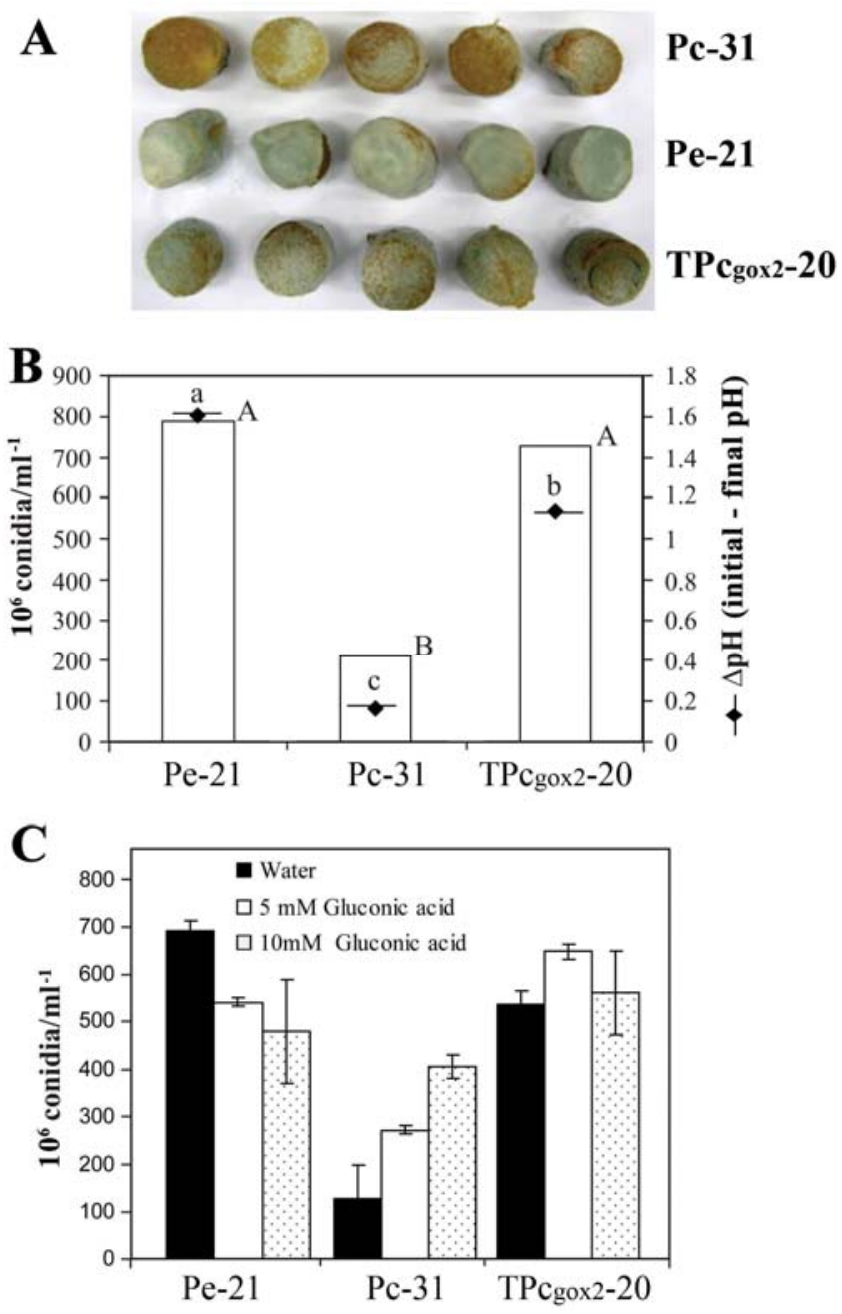

Fig. 5. Effects of the recombinant strain $\mathrm{TPc}_{\mathrm{gox} 2}-20$ on colonization and conidiation on pear fruit. A, Depiction of the colonization and conidiation observed on pear (Pyrus communis 'Spadona') disks $48 \mathrm{~h}$ after inoculation with Penicillium expansum (Pe-21), P. chrysogenum (Pc-31), and the recombinant $P$. chrysogenum strain $\mathrm{TPc}_{\mathrm{gox} 2}-20$, all at $10^{6}$ conidia/ml. B, Counts of the numbers of conidia produced on pear disks infected with the various mutants, and host acidification levels $(\bullet)$. Following inoculation, disks in a glass petri dish were incubated at $25^{\circ} \mathrm{C}$ for $48 \mathrm{~h}$ in darkness. Values presented are means of three replicates, and tests were repeated three times. Columns with different letters represent values that are significantly different $(P \leq 0.05)$ according to the Tukey-Kramer multiple comparison test. C, Effects of exogenous application of 5 and $10 \mathrm{mM}$ gluconic acid on conidiation and colonization by $P$. expansum and $P$. chrysogenum Wildtype and glucose oxidase $(G O X) 2$-expressing strains. Average values \pm standard deviation of three replicates are presented. the extent of restoring conidial counts to the level in the control (results not shown).

\section{pH regulation of germination \\ in $P$. expansum and $P$. chrysogenum.}

To determine the importance of initial $\mathrm{pH}$ and GLA production on the initial stages of germination and hyphal growth, $P$. expansum $\mathrm{Pe}-21$ strain was grown at five different $\mathrm{pH}$ levels of 3.0 to 7.0; conidial germination rate and hyphal biomass both decreased gradually as $\mathrm{pH}$ increased from 3.0 to 7.0 (Table 4). Interestingly, the decline in biomass formation was accompanied by an increase in the amount of GLA and a concomitant reduction in the $\mathrm{pH}$ of the medium. These results suggest that low $\mathrm{pH}$ enhanced spore germination and fungal growth but negatively affected GLA production.

To determine the specific effects of $\mathrm{pH}$ and GLA on germination and biomass development, strains Pe-21 and Pc-31, which differ in GLA production (Fig. $4 \mathrm{~B}$ ), and strain $\mathrm{TPc}_{\mathrm{gox} 2^{-}}$ 20, which accumulates GLA at higher levels than the parental strain Pc-31, were examined for differences in germ-tube formation during growth in $\mathrm{SM}$ at $\mathrm{pH} 7.0$. Within $7 \mathrm{~h}, 72 \%$ of $\mathrm{Pc}$ -
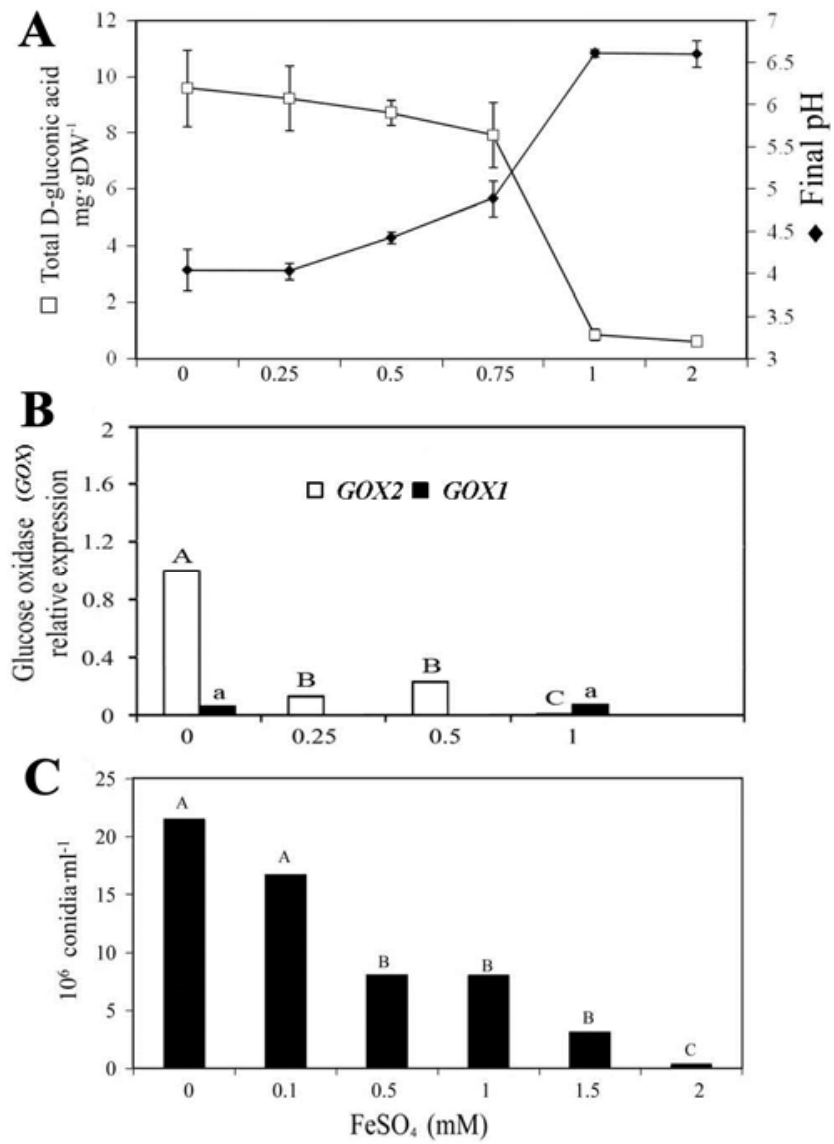

Fig. 6. Effects of $\mathrm{FeSO}_{4}$ on total D-gluconic acid (GLA) accumulation, media acidification, and Penicillium expansum colonization of pear disks. A, Effect of $\mathrm{FeSO}_{4}$-amended secondary medium adjusted to $\mathrm{pH} 7.0$ on total GLA accumulation and medium acidification. B, Expression analysis of glucose oxidase $(G O X) 1(\square)$ and $G O X 2(\square)$. Expression levels of $G O X 1$ and $G O X 2$ were compared with the respective levels of each gene without $\mathrm{FeSO}_{4}$. C, Conidia production by $P$. expansum on disks supplemented with $\mathrm{FeSO}_{4}$. Treated disks of 'Spadona' pear were placed in a glass dish following inoculation and incubated at $25^{\circ} \mathrm{C}$ for $48 \mathrm{~h}$ in darkness, and conidia were counted. Columns with different letters represent values that differ significantly $(P \leq 0.05)$ according to the Tukey-Kramer multiple comparison test. Means \pm standard deviation of three replicates are presented; tests were repeated three times and results of a single representative experiment are shown. 
31 conidia developed a germination tube whereas, in contrast, germ-tube formation in strains $\mathrm{Pe}-21$ and $\mathrm{TPc}_{\mathrm{gox} 2}-20$ had reached only 26 and $35 \%$, respectively (Table 5). In addition to its early germination, the biomass of strain Pc-31 was 2.5 times greater than those of strains Pe-21 and $\mathrm{TPc}_{\mathrm{gox} 2}-20$. However, addition of $\mathrm{Fe}$ at the GLA-inhibiting concentration of 1 $\mathrm{mM}$ resulted in increased biomass formation by strain Pe-21 and the $\mathrm{TPc}_{\mathrm{gox} 2}-20$ mutant, similar to that observed in strain Pc-31. These results suggest that either the potential for GLA production or GLA accumulation itself negatively affects Penicillium germination processes.

\section{DISCUSSION}

The pathogen $P$. expansum can acidify its host's tissue by secreting organic acids, of which GLA is the major factor in this process (Prusky et al. 2004). A previous study by Hadas and associates (2007) demonstrated the presence of two GOX genes encoding GOX. In the present study, we have used a transgenic approach to analyze the contribution of these two genes to the acidification process and pathogenicity.

\section{Differential regulation of $G O X$ expression, GOX activity, and GLA accumulation by ambient $\mathbf{p H}$.}

$P$. expansum accumulated GLA in a $\mathrm{pH}$-dependent manner that was closely regulated only by $G O X 2$ expression: neutral and alkaline conditions ( $\mathrm{pH} 7.0$ to 9.0) induced production of GLA at 5.7 to $4.8 \mathrm{mg}$ per gram of DW, respectively, whereas, at acidic conditions ( $\mathrm{pH} 4.0)$ under which GOX1 is highly expressed, GLA accumulation in the medium was marginal. Similarly to the response of $P$. variabile (Crognale et al. 2006), GOX activity was strongly dependent on $\mathrm{pH}$, being about 800 times higher at $\mathrm{pH} 7.0$ than at $\mathrm{pH}$ 4.0. The relatively high GOX1 expression at $\mathrm{pH} 4.0$ might account for the higher proportion $(65 \%)$ of intracellular GLA among total GLA than its proportion (only 25\%) found at $\mathrm{pH} 7.0$. These findings suggest that, at $\mathrm{pH} 4.0$, production and secretion of GLA by the fungus were significantly lower than at $\mathrm{pH}$ 7.0. Similar findings of transcript accumulation without organic acid accumulation

Table 4. Germination, total D-gluconic acid (GLA), and biomass production for Penicillium expansum wild type (WT) cultivated at a range of $\mathrm{pH}$ levels ${ }^{\mathrm{a}}$

\begin{tabular}{lcccc}
\hline $\mathbf{p H}$ & $\begin{array}{c}\text { Germination } \\
(\boldsymbol{\%})\end{array}$ & $\begin{array}{c}\text { Biomass } \\
(\mathbf{g} \text { DW) }\end{array}$ & $\begin{array}{c}\text { Total GLA } \\
\left(\mathbf{m g ~ g D W}^{-1}\right)\end{array}$ & \multicolumn{1}{c}{$\begin{array}{c}\Delta \mathbf{p H} \\
\text { (initial-final) }\end{array}$} \\
\hline 3 & $70 \pm 4.2$ & $0.3352 \pm 0.09$ & $0.54 \pm 0.04$ & $-1.09 \pm 0.23$ \\
4 & $73 \pm 1.3$ & $0.2243 \pm 0.08$ & $0.58 \pm 0.05$ & $-0.41 \pm 0.15$ \\
5 & $60 \pm 1.2$ & $0.2075 \pm 0.03$ & $5.25 \pm 0.45$ & $0.83 \pm 0.12$ \\
6 & $31 \pm 1.4$ & $0.1535 \pm 0.06$ & $17.08 \pm 1.01$ & $2.37 \pm 0.22$ \\
7 & $25 \pm 1.2$ & $0.0964 \pm 0.04$ & $27.2 \pm 0.90$ & $3.05 \pm 0.21$ \\
\hline
\end{tabular}

${ }^{a}$ Analysis was carried out in liquid secondary medium adjusted to the required $\mathrm{pH}$ as indicated and inoculated with WT Pe-21 at $10^{6} \mathrm{conidia} / \mathrm{ml}$ and incubated at $25^{\circ} \mathrm{C}$. Germ-tube formation was scored visually via a microscope after $7 \mathrm{~h}$. Biomass, GLA, and acidification were determined after $72 \mathrm{~h}$. Values presented are averages \pm standard deviation of three independent experiments. have been reported for goxC and oxaloacetate hydrolase (oahA) in $A$. niger, when both were expressed under conditions under which GLA and oxalic acid did not accumulate (Andersen et al. 2009).

Given that $P$. expansum requires a wound for successful penetration and colonization, reactive oxygen species (ROS) produced at early time points as a consequence of wound responses might be critical for $G O X$ activation and fungal ROS production (Hadas et al. 2007). Therefore, generated superoxide and subsequently generated ROS may act as second messengers that regulate the transcription of hypoxic genes such as GOX and activate its involvement in pathogenicity of Penicillium (Dutton and Evans 1996; Hadas et al. 2007; Kalisz et al. 1997). Given that $\mathrm{H}_{2} \mathrm{O}_{2}$ generation by $P$. expansum is added to the massive ROS accumulation at the lesion site, ROS contribution to the regulation of pathogenicity is a viable possibility .

\section{GLA is required for colonization and conidiation by $P$. expansum.}

Functional analysis of the goxRNAi mutants showed that modulation of GLA level affected not only the pathogen's interaction with the host but also its germination. The greater downregulation of GOX2 that was observed in the TPe130 and TPe141 mutants than in the TPe116 mutant strongly impaired the ability to produce GLA, acidify the medium, and infect apple fruit. A second approach to functionally analyze the contribution of GOX2 to pathogenicity involved its heterologous expression in the nondeciduous-fruit pathogen, $P$. chrysogenum. Expression of $P$. expansum GOX2 in $P$. chrysogenum on susceptible pear-fruit disks enhanced GLA production, acidification of the medium, surface colonization, and production of conidia; however, fruit colonization was still limited compared with that by strain Pe-21. These results indicate that the observed increase in GLA production is a factor that promotes surface colonization and sporulation, although complete pathogenicity would still require the expression of other pathogenicity factors, whose relevance to $P$. chrysogenum pathogenicity has not yet been studied (Mohammad-Saeid et al. 2010). Similarly, pathogenicity of oxalate-deficient mutants of Sclerotinia sclerotiorum on all host plants (Godoy et al. 1990) and of Botrytis cinerea on bean and grapevine leaves also correlated with the amounts of oxalic acid produced by various strains (Kars and van Kan 2007; Kunz et al. 2006).

The GLA production observed during $P$. expansum pathogenicity led us to examine an additional function of GLA: as a divalent-cation chelating agent. Increasing Fe concentration (at 0 to $2 \mathrm{mM}$ ) increasingly repressed GLA accumulation. In light of the facts that organic acids are known for their capacity to solubilize divalent cations (De Werra et al. 2009; Howard 1999) and that iron is an essential cofactor of many enzymes and cell processes (Schretti et al. 2007), we studied the role of GLA in iron acquisition. Under acidic conditions, iron can accumulate at the cell surface and be mobilized into the cell whereas, under alkaline conditions, it might be a major growthlimiting factor (Serrano et al. 2004; Winkelmann 1979). Present

Table 5. Effect of heterologous expression of glucose oxidase 2 (GOX2) on Penicillium chrysogenum and iron availability on germination and biomass production $^{\mathrm{a}}$

\begin{tabular}{|c|c|c|c|c|c|}
\hline \multirow[b]{2}{*}{ Strain } & \multicolumn{3}{|c|}{ SM } & \multicolumn{2}{|c|}{ SM +1 mM ferric } \\
\hline & Germination 7 h (\%) & Biomass (g DW) & $\Delta \mathrm{pH}$ & Biomass (g DW) & $\Delta \mathrm{pH}$ \\
\hline Pe-21 & $26 \pm 1.6$ & $0.17 \pm 0.01$ & $3.30 \pm 0.02$ & $0.37 \pm 0.02$ & $0.62 \pm 0.17$ \\
\hline Pc-31 & $72 \pm 1.6$ & $0.42 \pm 0.01$ & $1.45 \pm 0.13$ & $0.39 \pm 0.09$ & $0.14 \pm 0.03$ \\
\hline $\mathrm{TPc}_{\mathrm{gox} 2^{-}}-20$ & $35 \pm 1.4$ & $0.17 \pm 0.04$ & $2.96 \pm 0.04$ & $0.38 \pm 0.01$ & $0.15 \pm 0.06$ \\
\hline
\end{tabular}

${ }^{\text {a }}$ Conidia of the respective fungal strains in suspensions containing $10^{6}$ conidia per milliliter were incubated at $25^{\circ} \mathrm{C}$ in secondary medium (SM) adjusted to $\mathrm{pH}$ 7.0. Germ-tube formation was scored visually via microscope after $7 \mathrm{~h}$. Biomass and acidification were determined after $48 \mathrm{~h}$. Values are shown as average \pm standard deviation for three independent experiments that gave similar results. 
results may indicate that the iron acquisition by GLA might modulate pathogenicity by affecting GOX2 expression and reducing GLA accumulation, as required for the onset of disease development. This concept is equivalent to the role of oxalic acid and $\mathrm{Ca}^{2+}$ chelation in suppression of defense responses to S. sclerotiorum (Bateman and Beer 1965; Cessna et al. 2000; Magro et al. 1984; Martell and Calvin 1952; Rollins and Dickman 2000). Taken together, the present findings for the $P$. expansum-pear fruit interaction provide evidence that secreted GLA is important for the manifestation and regulation of full virulence in the host.

\section{GLA production attenuates germination in $P$. expansum.}

Present results indicate that conidial germination and mycelia growth in $P$. expansum are $\mathrm{pH}$ dependent: under acidic conditions in which GLA production is repressed, germination and biomass formation were promoted (Table 5). The role of low $\mathrm{pH}$ in germination has been established for Penicillium spp. such as P. notatum (Martin and Nicolas 1970), P. atrovenetum (Godoy et al. 1990; Gottlieb and Tripathi 1968), P. digitatum (Pelser and Eckert 1976), and P. expansum (Li et al. 2010). At neutral $\mathrm{pH}, P$. chrysogenum strains showed earlier germination and increased biomass compared with $P$. expansum, in which germination was delayed and GLA was produced abundantly. Biomass increase for strains Pe-21 and $\mathrm{TPc}_{\mathrm{gox} 2}-20$ could be attained to the level of the Pc-31 strain by Fe supplementation to the medium. Likewise, spores of A. niger have also been shown to contain GOX and to produce high levels of GLA, as long as germination was completely inhibited (Moksia et al. 1996; Ramachandran et al. 2007). In Pseudomonas fluorescens, mutants with impaired GLA production grew faster and formed bigger colonies than those with normal GLA production (De Werra et al. 2009). A possible interpretation of these interactions is that, in gox-RNAi strains, a reduction in the direct oxidative pathway induce conidial germination and biomass production (De Werra et al. 2009). The data regarding the conditions under which GLA is likely to be produced and the consequences of $\mathrm{Fe}$ availability provide a tool for elucidating the mechanism that triggers swelling and germ-tube formation in Penicillium expansum.

The results presented here provide a putative mechanism by which $P$. expansum regulates both $G O X$ genes in a manner dependent on the initial ambient $\mathrm{pH}$ of any particular host. Thus far, GOX2 appears to play the major role in regulating GOX activity. At neutral $\mathrm{pH}, P$. expansum conidia were subjected to GLA production, which represses conidial germination but prepares the host tissue for mycelial invasion, by acidifying it to ensure successful host colonization. The role of GLA production during later stages of colonization is to ensure local acidification, which is continuously required in the leading-edge zone. Therefore, we suggest that the machinery which dynamically responds to ambient intercellular or intracellular $\mathrm{pH}$ within the host is an important component of $P$. expansum virulence, and that it is required by the pathogen during colonization.

\section{MATERIALS AND METHODS}

\section{Fungal strains and culture conditions.}

The wild-type Pe-21 isolate of $P$. expansum was obtained from decayed Golden Delicious apple fruit purchased from a local market in Israel (Hadas et al. 2007). Wild-type P. chrysogenum Pc-31 was obtained from previous collections of Penicillium isolates in Israel and was identified molecularly. Cultures were grown at $27^{\circ} \mathrm{C}$ in darkness and maintained on PDA plates (Difco Laboratories, Detroit) unless otherwise indicated. Conidia were harvested with $10 \mathrm{ml}$ of sterile distilled water supplemented with $0.01 \%$ (vol/vol) Tween 80 (Sigma-Aldrich,
St. Louis). When required, antibiotics were added to the growth medium at the following concentrations: hygromycin B, 250 $\mu \mathrm{g} / \mathrm{ml}$ (Roche, Mannheim, Germany) or phleomycin, $60 \mu \mathrm{g} / \mathrm{ml}$ (Invitrogen, Carlsbad, CA, U.S.A.). Cells were visualized with a model BX60F-3 microscope and a model SZ-60 stereoscope (Olympus America, Inc., Melville, NY, U.S.A.).

\section{Assay for surface conidiation and colonization, and disease development.}

For surface conidiation and colonization studies, pear disks (Pyrus communis 'Spadona'), $1.5 \mathrm{~cm}$ in diameter and $0.5 \mathrm{~cm}$ thick, were prepared prior to inoculation. For inoculation, five pear disks were immersed for $3 \mathrm{~h}$ in $30 \mathrm{ml}$ of a suspension of spores of the indicated strain in sterile distilled water at $10^{6}$ spores $/ \mathrm{ml}$. The suspension with the disks was subjected to continuous horizontal shaking at $80 \mathrm{rpm}$. The infected pear disks were then placed on a water-saturated filter paper in a glass petri dish and incubated for 24 or $48 \mathrm{~h}$, as indicated, at $25^{\circ} \mathrm{C}$ in darkness. To count the number of spores produced, the disks were placed in a 50-ml tube containing $10 \mathrm{ml}$ of sterile water supplemented with $0.01 \%$ Tween 80 , and vortexed for $1 \mathrm{~min}$. Spores in a $20-\mu$ l aliquot of the spore suspension were counted with a hemocytometer, with uninfected pear disks used as controls. To study the effects of gluconic acid or iron ions on colonization and conidiation, the conidial suspension was supplemented with 5 or $10 \mathrm{mM}$ gluconic acid (Sigma-Aldrich) or $\mathrm{FeSO}_{4}$ at 0.25 to $2 \mathrm{mM}$, respectively. No effect of the $\mathrm{FeSO}_{4}$ on fungal radial growth was observed. One representative experiment out of three separate repetitions that yielded similar results is presented.

For disease development assessments, apple and pear fruit were inoculated by placing $10 \mu \mathrm{l}$ of a conidial suspension containing $2 \times 10^{6}$ spores/ml on each of four 2-mm-deep, 2-mmdiameter wounds spaced around a circle on the upper part of the stem side of the fruit. Following inoculation, the fruit were incubated at $25^{\circ} \mathrm{C}$ in covered plastic containers containing wet paper towels, until decay symptoms developed. To analyze the effects of Fe on decay development, the fruit wound sites were treated every $24 \mathrm{~h}$ with $50 \mu \mathrm{l}$ of $\mathrm{FeSO}_{4}$ at various concentrations.

\section{Analysis and quantification of total GLA production by Penicillium expansum.}

To evaluate the total GLA (i.e., free GLA and D-glucono- $\delta$ lacton) level in culture, fungal spores at $10^{6} \mathrm{spores} / \mathrm{ml}$ were inoculated into $40 \mathrm{ml}$ of a primary medium (i.e., glucose minimal medium) in 125-ml flasks containing $10 \mathrm{~g}$ of sucrose, $5 \mathrm{~g}$ of yeast extract (Difco Laboratories), $50 \mathrm{mg}$ of nitrate salts, and $1 \mathrm{mg}$ of trace elements per liter, at $\mathrm{pH}$ 6.5. The cultures were incubated at $25^{\circ} \mathrm{C}$ with shaking at $150 \mathrm{rpm}$ for $48 \mathrm{~h}$. Cultures were harvested by vacuum filtration through a sterile Büchner funnel fitted with a filter paper (Whatman number 1), and the remaining mycelia were washed twice with $50 \mathrm{ml}$ of sterile distilled water. The washed mycelia were resuspended in $50 \mathrm{ml}$ of a GA-inducing SM containing $60 \mathrm{~g}$ of sucrose, $7 \mathrm{~g}$ of $\mathrm{NaNO}_{3}, 3 \mathrm{~g}$ of tryptone (Difco Laboratories), $1 \mathrm{~g}$ of $\mathrm{KH}_{2} \mathrm{PO}_{4}, 0.5 \mathrm{~g}$ of $\mathrm{MgSO}_{4} \cdot 7 \mathrm{H}_{2} \mathrm{O}$, and $0.5 \mathrm{~g}$ of $\mathrm{KCl}$ per liter, adjusted to $\mathrm{pH} 7.0$. The culture was incubated at $25^{\circ} \mathrm{C}$ on a rotating shaker at $150 \mathrm{rpm}$ for $48 \mathrm{~h}$. For experiments with modified $\mathrm{pH}$, the initial $\mathrm{pH}$ of the $\mathrm{SM}$ was adjusted to the desired level with either $10 \mathrm{~N} \mathrm{NaOH}$, concentrated $\mathrm{HCl}$, or $0.2 \mathrm{M}$ potassium phthalate buffer, as indicated. For analysis of the effects of divalent cations on GLA production, the corresponding salts- $\mathrm{MgSO}_{4}, \mathrm{MnSO}_{4}, \mathrm{CuCl}_{2}, \mathrm{CaCl}_{2}, \mathrm{FeSO}_{4}$ and $\mathrm{ZnSO}_{4}-$ were added to the SM at the indicated concentrations and the $\mathrm{SM}$ was adjusted to $\mathrm{pH} 7.0$. After $48 \mathrm{~h}$ of growth, aliquots of the suspensions were collected and the amounts of GLA produced were measured with an enzymatic method for mea- 
suring total GLA content (free GLA and D-glucono- $\delta$-lactone) (catalog number 10428191035; Boehringer Mannheim, Darmstadt, Germany), used according to the manufacturer's instructtions. Extracellular (in culture filtrate) or intracellular (within the mycelia) levels of total GLA were analyzed. The supernatant was used for measuring $\mathrm{pH}$ level and extracellular GLA accumulation; intracellular GLA accumulation was determined by grinding the frozen mycelia in a microcentrifuge tube in the presence of $1 \mathrm{ml}$ of $\mathrm{H}_{2} \mathrm{O}$. Similarly, mycelium was frozen in liquid nitrogen and lyophilized for determination of dry weight or extraction of RNA.

\section{Assay of GOX activity.}

GOX activity was measured at various time points, as described by Hadas and associates (2007), in culture filtrates of secondary media that were adjusted to the desired $\mathrm{pH}$ levels, with or without buffer. To study the effect of the incubation period on GOX activity, a fraction of the SM was removed and its GOX activity was determined as a function of the time elapsed since transfer of mycelia to it. The effect of $\mathrm{pH}$ on enzyme activity was determined for $\mathrm{pH}$ of 4 to 6.86 ; cultures were harvested by vacuum filtration after $48 \mathrm{~h}$, and the GOX activity in the filtrate was assayed. Samples were concentrated by filtration through an Amicon Ultra 30,000 MWCO centrifugal filter device (Millipore Corporation, Bedford, MD, U.S.A.), and the GOX activity was measured. The control for GOX production in vitro was the inoculated secondary medium, used immediately after addition of the hyphae. The reaction mixtures contained $20 \mu \mathrm{g}$ of horseradish peroxidase type 1 (Sigma-Aldrich), $1.8 \%$ D-glucose, $0.1 \%$ o-dianisidine (Sigma-Aldrich), and $100 \mu \mathrm{l}$ of the sample, in $1.5 \mathrm{ml}$ of $0.1 \mathrm{M}$ potassium phosphate buffer at $\mathrm{pH} 6.5$, as described by Hadas and associates (2007). The oxidation of o-dianisidine in a peroxidase-coupled reaction was indicated by the increase in the absorbance at $460 \mathrm{~nm}$ : one unit of activity was defined as the amount of enzyme that caused absorbance at $460 \mathrm{~nm}$ to increase by one unit per minute at $25^{\circ} \mathrm{C}$ and $\mathrm{pH}$ 6.5. Protein concentrations in samples were measured with the Protein-Assay instrument (Bio-Rad Laboratories, Munich, Germany), with bovine serum albumin (SigmaAldrich) used as the standard. Measurements of the GOX activities were repeated three times in order to examine reproducibility; the results of representative measurements are presented.

\section{pH measurements.}

The $\mathrm{pH}$ was measured with a single-pore flat or double-pore slim electrode (Hamilton, Bonaduz, Switzerland) connected to a Thermo Orion Model 720A Plus pH meter (Orion, Beverly, MA, U.S.A.). The $\mathrm{pH}$ of the medium was measured in 3-ml aliquots sampled after fungal inoculation, and at least three measurements per sample were taken. The $\mathrm{pH}$ of the mesocarp was measured by placing the $\mathrm{pH}$ electrode directly against the exposed tissue at several points along a transverse cut through the infection site. All in planta measurements were repeated five times with the same tissue section.

\section{Cloning and extending the $G O X$ gene fragments from $P$. expansum.}

A 760-bp GOX 2 fragment cloned by Hadas and associates (2007) (GenBank accession number DQ157372) was extended to 2.64-kb by means of the GenomeWalker Universal Kit (Clontech, Palo Alto, CA, U.S.A.) deposited as GenBank accession number GQ324948. A 2.53-kb GOX2 fragment, including the full length of the $5^{\prime}$ upstream region and the complete $3^{\prime}$ terminus of the gene that was used in the recombinant $P$. chrysogenum experiment, was amplified by using the oligonu- cleotides FGOX2-63 and RGOX2-2 (Table 3). The GOX1 partial-coding sequence (GenBank accession number AY669127) was amplified by using the primer pair FGOX1-54 and FGOX1-173.

\section{Nucleic acid analysis.}

Extraction of DNA from fungi, restriction-enzyme digestion, and gel electrophoresis was performed by standard methods (Sambrook et al. 1989). Total RNA from pear tissues was isolated from three zones of a 3-day-developed lesions (center, leading edge, and healthy tissue) of three pear fruit using the method described earlier (Lopez-Gomez and Gomez-Lim 1992). Frozen tissue ( $4 \mathrm{~g})$ was ground in a mortar and pestle. The frozen powder was added to $10 \mathrm{ml}$ of lysis buffer (2\% sodium dodecyl sulfate [SDS], $1 \%$ mercaptoethanol, $50 \mathrm{mM}$ ethylenediaminetetraacetic acid [EDTA], and $150 \mathrm{mM}$ Tris base with $\mathrm{pH}$ adjusted to 7.5 with $1 \mathrm{M}$ boric acid at 2 to $3 \mathrm{ml} \mathrm{g}^{-1}$ of fresh tissue) at room temperature. The homogenate was quickly vortexed for $1 \mathrm{~min}$ with 0.25 volumes of absolute ethanol and 0.11 volumes of $5 \mathrm{M}$ potassium acetate. An equal volume of chloroform/isoamyl (49:1) was added, followed by strong vortexing, and the homogenate was centrifuged at $15,000 \times g$ for $20 \mathrm{~min}$. The aqueous phase was extracted twice with phenol/ chloroform (1:1) and once with chloroform/isoamyl alcohol (49:1). The RNA was precipitated overnight with $3 \mathrm{M}$ lithium chloride (final concentration) at $-20^{\circ} \mathrm{C}$ and collected by centrifugation at $15,000 \times g$ for $90 \mathrm{~min}$ at $4^{\circ} \mathrm{C}$. The RNA was then resuspended in $500 \mu \mathrm{l}$ of $0.1 \%$ diethylpyrocarbonate (DEPC)treated sterile water and precipitated with $0.3 \mathrm{M}$ potassium acetate (final concentration) and two volumes of absolute ethanol. After overnight incubation at $-20^{\circ} \mathrm{C}$, the RNA was repelleted by centrifugation at $15,000 \times g$ for $90 \mathrm{~min}$ at $4^{\circ} \mathrm{C}$, washed twice with $75 \%$ ethanol, and resuspended in the DEPC-treated water. Purity of the extracted RNA was assayed by ND-1000 spectrophotometer (NanoDrop Technologies Inc., U.S.A., Wilmington, DE, U.S.A.), and stored at $-80^{\circ} \mathrm{C}$ until further analysis.

\section{Construction and characterization of GOX RNA $i$ mutants.}

To assess the functions of $G O X$-encoding genes, strains in which GOX2 was silenced were generated by RNAi technology by using the inverted repeat transgene of the GOX2 sequence. The silencing vector pSilent-1 (Nakayashiki et al. 2005) was used to generate the goxRNAi construct. An 800-bp fragment of $G O X 2$ with no predicted introns was amplified by using the primers (Table 3) GOXFwd single (5' GOX KpnI/XhoI 3') and GOXRev single (5' GOX HindIII/SphI $\left.3^{\prime}\right)$. The resulting fragment contained the engineered restriction sites $5^{\prime}$ GOX XhoI/ HindIII and 3' GOX SphI/KpnI. First, the restriction sites XhoI and HindIII were used to insert the fragment in the forward orientation into pSilent-1 to create p3. Next, the restriction sites $S p h \mathrm{I}$ and $K p n I$ were used to insert the fragment in the reverse orientation to create p3.4. The resulting plasmid p3.4 was used in Pe-21 transformation.

Fungal transformation of protoplasts was performed essentially according to Miller and associates (1985). Isolated hygromycin-resistant colonies were screened for GLA production in 48-well microplates that contained $1 \mathrm{ml}$ of SM per well. The wells were inoculated with a single hyphal "ball" (1 to 2 $\mathrm{mm}$ in diameter) that had been grown in the primary medium. After $24 \mathrm{~h}$, the SM was supplemented with $0.01 \%$ (vol/vol) of the $\mathrm{pH}$ indicator Alizarin Red S (Sigma-Aldrich); strains that acidified the medium to below $\mathrm{pH} 4.5$ changed its color to yellow, whereas the medium remained red in cases of impaired acidification capability. Strains exhibiting impaired acidification capability were tested by PCR for the presence of the hygromycin fragment: a $0.75-\mathrm{kb}$ PCR fragment was obtained 
by using forward and reverse primers from the hygromycin cassette (Fhyg and Rhyg, respectively) (Table 3 ).

\section{Generating transgenic recombinant}

$P$. chrysogenum expressing $P$. expansum GOX2 gene.

Heterologous expression of the GOX2 gene in the wild-type $P$. chrysogenum Pc-31 strain was achieved by using the vector pCH1. Plasmid pCH1 was generated by cloning a $2.53-\mathrm{kb}$ fragment of a full-length $G O X 2$ coding sequence into $\mathrm{pBC}$ Phleo, driven by A. nidulans gpdA promoter and the Saccharomyces cerevisiae $\mathrm{CYC1}$ terminator, and carrying the phleomycin resistance cassette (He et al. 2007). Integration of pCH1 into the Pe-21 genome was confirmed by PCR amplification of $0.2 \mathrm{~kb}$ of the ble gene by using the primer pair Phleo.F and Phleo.R (Solomon et al. 2008). Transformation was done as described above. The wild-type $P$. chrysogenum was confirmed as such by comparison of the internal transcribed spacer region with the GenBank sequence.

\section{Expression analysis of $G O X 1$ and $G O X 2$ by quantitative RT-PCR analysis.}

To examine GOX1 and GOX2 expression, cultures of wildtype Pe-21 RNAi mutants were cultured as indicated above for measurement of GLA level. RNA was extracted from $80-\mathrm{mg}$ samples of frozen mycelia with the SV Total RNA Isolation System (Promega Corp., Madison, WI, U.S.A.), and residual DNA was removed by treatment with TURBO DNA Free (Ambion, Austin, TX, U.S.A.). In planta RNA extraction from pear plant tissue was performed according to Folta and associates (2005). Briefly, $1 \mathrm{~g}$ of tissue was ground in liquid nitrogen with a mortar and pestle, then incubated at $65^{\circ} \mathrm{C}$ for $10 \mathrm{~min}$ in extraction buffer comprising $2 \%$ cetyltrimethylammonium bromide, $2 \%$ polyvinylpyrrolidone, $100 \mathrm{mM}$ Tris- $\mathrm{HCl}(\mathrm{pH} 8.0)$, $25 \mathrm{mM}$ EDTA, 2.0 M NaCl, spermidine at $0.5 \mathrm{~g} / \mathrm{ml}$, and $2.0 \%$ $\beta$-mercaptoethanol. The samples were cooled to room temperature, an equal volume of chloroform/octanol mixture (24:1) was added, and the mixture was homogenized. The organic and aqueous phases were separated by centrifugation and the supernatant was vortexed with an equal volume of chloroform/ octanol. The phases were again separated by centrifugation and the supernatant was transferred to a clean tube. $\mathrm{LiCl}$ was added to a final concentration of $2.5 \mathrm{M}$, and RNA was precipitated on ice overnight and then collected by centrifugation. The pellet was resuspended in $500 \mu \mathrm{l}$ of SSTE (comprising 1 $\mathrm{M} \mathrm{NaCl}, 0.5 \%$ SDS, $10 \mathrm{mM}$ Tris- $\mathrm{HCl}[\mathrm{pH} 8.0]$, and $1 \mathrm{mM}$ EDTA) and extracted with an equal volume of chloroform/octanol $(24: 1)$ mixture. The supernatant was precipitated with two volumes of ethanol containing $0.3 \mathrm{M}$ sodium acetate, and the pellet was washed with $76 \%$ ethanol, dried in a Speed Vac, and resuspended in $50 \mu \mathrm{l}$ of $10 \mathrm{mM}$ Tris- $\mathrm{HCl}(\mathrm{pH} \mathrm{8.0)}$ and 2.5 mM EDTA. Residual DNA was then removed by treatment with TURBO DNA Free (Ambion) before quantification by spectrophotometry. The reverse-transcription reaction was performed on $1 \mu \mathrm{g}$ of total RNA with the Reverse-it First-Strand Synthesis Kit (ABgene, Surrey, U.K.), and cDNA samples were diluted 1:10 with ultrapure water.

Real-time quantitative PCR was performed with the RotorGene 3000 system (Corbett Research, Sydney, Australia). PCR amplification was performed with $3.6 \mu$ l of cDNA template in $10 \mu \mathrm{l}$ of a reaction mixture containing $5 \mu \mathrm{l}$ of SYBR-Green Amplification Kit (ABgene) and $300 \mathrm{nM}$ primers; the forward and reverse primers for the GOX 2 amplicon were FGOX2-290 and RGOX2-371, respectively; those for the GOX 1 amplicon were FGOX1-567 and RGOX1-657, respectively; and those for the 28S rRNA of $P$. expansum were F28S and R28S, respectively. Highly differential regions of the GOX1 and GOX2 sequences were selected for primer design. Results were ana- lyzed with the Rotor-Gene 6 software. The 28S rRNA gene served as an endogenous control and the calibration sample varied according to the experiment, as indicated. A mixture of all cDNAs was used in all treatments, as a template for calibration curves designed for each pair of primers, to verify that a single PCR product had been formed. Relative quantification was calculated with the $\Delta \Delta$ cycle threshold $\left(\mathrm{C}_{\mathrm{T}}\right)$ method (Livak and Schmittgen 2001). The $\Delta \mathrm{C}_{\mathrm{T}}$ value was determined by subtracting the $\mathrm{C}_{\mathrm{T}}$ results for the target gene from those for the endogenous control gene and normalizing against the calibration sample, to generate the $\Delta \Delta \mathrm{C}_{\mathrm{T}}$ values. Each experiment was performed in triplicate, and three different biological experiments were conducted, of which one representative set of results is presented. Mean values of $2^{\Delta \Delta C T} \pm$ standard deviation of each treatment were subjected to mean comparisons by least significant difference (LSD), according to the Tukey-Kramer Multiple Comparison Test at $P<0.05$.

\section{Statistical analysis.}

Data were analyzed with the JMP software package, version 3.2.6 (SAS Institute, Cary, NC, U.S.A.). Mean comparisons of GOX1 and GOX2 expression, gluconic acid production, and ambient $\mathrm{pH}$ measurements were analyzed according to LSD, with the Tukey-Kramer Multiple Comparison Test at $P \leq 0.05$. Frequencies of germination were pooled for each set of three replications per treatment or isolate, after application of Student's $t$ test to determine homogeneity of variance among the three independent experiments, and no statistically significant $(P<0.05)$ differences among experiments were found.

\section{ACKNOWLEDGMENTS}

This research was funded by the Israeli Foundation of Science, grant number 1266/2. We thank Y. Hadas for the methods based on GOX activity described in the article.

\section{LITERATURE CITED}

Andersen, M. R., Lehmann, L., and Nielsen, J. 2009. Systemic analysis of the response of Aspergillus niger to ambient pH. Genome Biol. 10:R47.

Barkai-Golan, R. 1974. Species of Penicillium causing decay of stored fruits and vegetables in Israel. Mycopathologia 54:141-145.

Bateman, D. F., and Beer, S. V. 1965. Simultaneous production and synergistic action of oxalic acid and polygalacturonase during pathogenesis by Sclerotium rolfsii. Phytopathology 58:204-211.

Bruchmana, E. E., Schach H., and Graf, H. 1987. Role and properties of lactonase in a cellulase system. Biotechnol. Appl. Biochem. 9:146-159.

Cessna, S., Sears, V., Dickman, M., and Low, P. 2000. Oxalic acid, a pathogenicity factor of Sclerotinia sclerotiorum, suppresses the host oxidative burst. Plant Cell 12:2191-2199.

Crognale, S., Pulci, V., Brozzoli, V., Petruccioli, M., and Federici, F. 2006. Expression of Penicillium variabile P16 glucose oxidase gene in Pichia pastoris and characterization of the recombinant enzyme. Enzyme Microbiol. Technol. 39:1230-1235.

De Werra, P., Péchy-Tarr, M., Keel, C., and Maurhofer, M. 2009. Role of gluconic acid production in the regulation of biocontrol traits of $\mathrm{Pseu}$ domonas fluorescens CHAO. Appl. Environ. Microbiol. 75:4162-4174.

Dutton, M. V., and Evans, C. S. 1996. Oxalate production by fungi: Its role in pathogenicity and ecology in the soil environment. Can. J. Microbiol. 42:881-895.

Eisendle, M., Oberegger, H., Zadra, I., and Haas, H. 2003. Biosynthesis and uptake of siderophores is controlled by the pacC-mediated ambient$\mathrm{pH}$ regulatory system in Aspergillus nidulans. Eukaryot. Cell 3:561563.

Emanuelsson, O., Nielsen, H., Brunak, S., and von Heijne, G. 2000. Predicting subcellular localization of proteins based on their N-terminal amino acid sequence. J. Mol. Biol. 300:1005-1016.

Folta, K. M., Staton, M., Stewart, P. J., Jung, S., Bies, D. H., Jesdurai, C. and Main, D. 2005. Expressed sequence tags (ESTs) and simple sequence repeat (SSR) markers from octoploid strawberry (Fragaria $\times$ ananassa). BMC Plant Biol. 5:12.

Godoy, G., Steadman, J. R., Dickman, M. B., and Dam, R. 1990. Use of mutants to demonstrate the role of oxalic acid in pathogenicity of 
Sclerotinia sclerotiorum on Phaseolus vulgaris. Physiol. Mol. Plant Pathol. 37:179-191.

Gottlieb, D., and Tripathi, R. K. 1968. The physiology of swelling phase of spore germination in Penicillium atrovenetum. Mycologia 60:571590.

Guerinot, M. L. 1994. Microbial iron transport. Annu. Rev. Microbiol. 48:743-772.

Hadas, Y., Goldberg, I., Pines, O., and Prusky, D. 2007. Involvement of gluconic acid and glucose oxidase in the pathogenicity of Penicillium expansum in apples. Phytopathology 97:384-390.

He, Z. M., Price, M. S., Obrian, G. R., Georgianna, D. R., and Payne, G. A. 2007. Improved protocols for functional analysis in the pathogenic fungus Aspergillus flavus. BMC Microbiol. 7:104.

Howard, D. H. 1999. Acquisition, transport, and storage of iron by pathogenic fungi. Clin. Microbiol. Rev. 12:394-404.

Kalisz, H. M., Hendle, J., and Schmid, R. D. 1997. Structural and biochemical properties of glycosylated and deglycosylated glucose oxidase from Penicillium amagasakiense. Appl. Microbiol. Biotechnol. 47:502507.

Kars, I., and van Kan, J. A. L. 2007. Extracellular enzymes and metabolites involved in pathogenesis of Botrytis. Pages 99-113 in: Botrytis: Biology, Pathology and Control. Y. Elad, B. Williamson, P. Tudzynski, and N. Delen, eds. Springer, Dordrecht, The Netherlands.

Kobayashi, M., Shinohara, M., Sakoh, C., Kataoka, M., and Shimizu, S. 1998. Lactone-ring cleaving enzyme: Genetic analysis, novel RNA editing and evolutionary implications. Proc. Natl. Acad. Sci. U.S.A. 95:12787-12792.

Kunz, C., Vandelle, E., Rolland, S., Poinssot, B., Bruel, C., Cimerman, A., Zotti, C., Moreau, E., Vedel, R., Pugin, A., and Boccara, M. 2006. Characterization of a new, nonpathogenic mutant of Botrytis cinerea with impaired plant colonization capacity. New Phytol. 170:537-550.

Li, B., Lai, T., Qin, G., and Tian, S. 2010. Ambient pH stress inhibits spore germination of Penicillium expansum by impairing protein synthesis and folding: A proteomic-based study. J. Proteome Res. 2010:298-307.

Livak, K. J., and Schmittgen, T. D. 2001. Analysis of relative gene expression data using real-time quantitative PCR and the $2-\Delta \Delta C T$ method. Methods 25:402-408.

Lopez-Gomez, R., Gomez-Lim, M. A. 1992. A method for extracting intact RNA from fruits rich in polysaccharides using ripe mango mesocarp. HortScience 27:440-442.

Magnuson, J. K., and Lasure, L. L. 2004. Organic acid production by filamentous fungi. Pages 307-340 in: Advances in Fungal Biotechnology for Industry, Agriculture, and Medicine. J. S. Tkacz and L. Lange, eds. Kluwer Academic/Plenum Publishers, New York.

Magro, P., Marciano, P., and Di Lenna, P. 1984. Oxalic acid production and its role in pathogenesis of Sclerotinia sclerotiorum. FEMS (Fed. Eur. Microbiol. Soc.) Microbiol. Lett. 24:9-12.

Manteau, S., Abouna, S., Lambert, B., and Legendre, L. 2003. Differential regulation by ambient $\mathrm{pH}$ of putative virulence factor secretion by the phytopathogenic fungus Botrytis cinerea. FEMS (Fed. Eur. Microbiol. Soc.) Microbiol. Ecol. 43:359-366.

Martell, E. A., and Calvin, M. 1952. Chemistry of Metal Chelate Compounds. Prentice-Hall, Inc., New York.

Martin, J. F., and Nicolas, G. 1970. Physiology of spore germination in Penicillium notatum and Trichoderma lignorum. Trans. Br. Mycol. Soc. 55:141-148

Miller, B. L., Miller, K. Y., and Timberlake, W. E. 1985. Direct and indirect gene replacement in Aspergillus nidulans. Mol. Cell Biol. 5:17141721

Mohammad-Saeid, J., García-Estrada, C., Barreiro, C., Cuadrado, A. A., Salehi-Najafabad, Z., and Martín, J. F. 2010. Mol. Cell. Proteom. 9:2729-2744
Moksia, J., Larroche, C., and Gros, J. B. 1996. Gluconate production by spores of Aspergillus niger. Biotechnol. Lett. 18:1025-1030.

Nakai, K., and Horton, P. 1999. PSORT: A program for detecting the sorting signals of proteins and predicting their subcellular localization. Trends Biochem. Sci. 24:34-35.

Nakayashiki, H., Hanada, S., Quoc, N. B., Kadotani, N., Tosa, Y., and Mayama, S. 2005. RNA silencing as a tool for exploring gene function in ascomycete fungi. Fungal Genet. Biol. 42:275-283.

Nielsen, H., Brunak, S., and von Heijne, G. 1999. Machine learning approaches to the prediction of signal peptides and other protein sorting signals. Protein Eng. 12:3-9.

Pelser, P. du T., and Eckert, J. W. 1976. Constituents of orange juice that stimulate the germination of conidia of Penicillium digitatum. Postharvest Res. Pathol. 67:747-754.

Prusky, D., and Yakoby, N. 2003. Pathogenic fungi: Leading or led by ambient $\mathrm{pH}$ ? Mol. Plant Pathol. 4:509-516.

Prusky, D., McEvoy, J. L., Saftner, R., Conway, W. S., and Jones, R. 2004. The relationship between host acidification and virulence of Penicillium spp. on apple and citrus fruit. Phytopathology 94:44-51.

Ramachandran, S., Fontanille, P., Pandey, A., and Larroche, C. 2007. Spores of Aspergillus niger as reservoir of glucose oxidase synthesized during solid-state fermentation and their use as catalyst in gluconic acid production. Lett. Appl. Microbiol. 44:155-160.

Rollins, J. A., and Dickman, M. B. 2000. pH signaling in Sclerotinia sclerotiorum: Identification of pacC/RIM1 homolog. Appl. Environ. Microbiol. 67:75-81.

Ruijter, G. J. G., van de Vondervoort, P. J. I., and Visser, J. 1999. Oxalic acid production by Aspergillus niger: An oxalate-non-producing mutant produces citric acid at $\mathrm{pH} 5$ and in the presence of manganese. Microbiology 145:2569-2576.

Sambrook, J., Fritsch, E. F., and Maniatis, T. 1989. Molecular Cloning: A Laboratory Manual. Cold Spring Harbor Laboratory Press, Cold Spring Harbor, NY, U.S.A

Sánchez-Torres, P., and González-Candelas, L. 2003. Isolation and characterization of genes differentially expressed during the interaction between apple fruit and Penicillium expansum. Mol. Plant Pathol. 4:447457.

Schretti, M., Bignell, E., Kragl, C., Sabiha, Y., Loss, O., Eisendle, M., Wallner, A., Arst, H. N., Jr., Haynes, K., and Haas, H. 2007. Distinct roles for intra- and extracellular siderophores during Aspergillus fumigatus infection. PLoS Pathog. 3:e128.

Serrano, R., Bernal, D., Simon, E., and Arino, J. 2004. Copper and iron are the limiting factors for growth of the yeast Saccharomyces cerevisiae in an alkaline environment. J. Biol. Chem. 279:19698-19704.

Solomon, P. S., Ipcho, S. V. S., Hane, J. K., Tan, K., and Oliver, R. P. 2008. A quantitative PCR approach to determine gene copy number. Fungal Genet. Rep. 55:5-8.

Winkelmann, G. 1979. Surface iron polymers and hydroxyl acids. A model of iron supply in sideramine-free fungi. Arch. Microbiol. 121:43-51.

Yao, C., Conway, W. S., and Sams, C. E. 1996. Purification and characterization of a polygalacturonase produced by Penicillium expansum in apple fruit. Phytopathology 86:1160-1166.

\section{AUTHOR-RECOMMENDED INTERNET RESOURCES}

The National Center for Biotechnology Information BLAST webpage: blast.ncbi.nlm.nih.gov/Blast.cgi

PSORTII protein prediction server: psort.ims.u-tokyo.ac.jp

Center for Biological Sequence Analysis (CBS) SignalP-HMM server: www.cbs.dtu.dk/services/SignalP

CBS TargetP server: www.cbs.dtu.dk/services/TargetP 